\title{
DROUGHT LIMITS INDUCED TWINING BY LEAF DAMAGE IN THE CLIMBING PLANT IPOMOEA PURPUREA (L.) ROTH (CONVOLVULACEAE)
}

\author{
LA SEQUIA LIMITA LA INDUCCIÓN DE TREPADO POR DAÑO FOLIAR \\ EN LA PLANTA TREPADORA IPOMOEA PURPUREA (L.) ROTH \\ (CONVOLVULACEAE)
}

\author{
Cristian Atala ${ }^{1,2} \&$ Ernesto Gianoli ${ }^{2,3,4}$
}

\begin{abstract}
${ }^{1}$ Departamento Forestal, Universidad de Concepción, Unidad Académica Los Ángeles, Juan Antonio Coloma 0201, Los Ángeles, Chile. ${ }^{2}$ Departamento de Botánica, Universidad de Concepción, Casilla 160-C, Concepción, Chile. ${ }^{3}$ Center for Advanced Studies in Ecology and Biodiversity (CASEB), P. Universidad Católica de Chile, Alameda 340, Santiago, Chile. ${ }^{4}$ Departamento de Biología, Universidad de La Serena, Casilla 599, La Serena, Chile. catala@udec.cl
\end{abstract}

\begin{abstract}
The environment may limit the expression of induced responses to herbivory, such as increased chemical or physical defenses. Recent studies in climbing plants have shown that leaf damage induces twining. This response may confer protection against ground herbivores in the field. We addressed the effect of drought on the induced twining of the annual vine Ipomoea purpurea (Convolvulaceae), which can experience drought stress in natural conditions. In a greenhouse experiment, we recorded twining rate (proportion of plants successfully climbing at a given time) of damaged and undamaged individuals of $I$. purpurea subjected to control watering and water shortage treatments. We also estimated stem growth rate and stem water content in experimental plants, just after the evaluation of climbing success. Plants in the drought treatment showed reduced twining induction by leaf damage compared to control plants. Neither stem growth nor stem water content were affected by leaf damage or drought. Results suggest that drought constrains the induced twining through mechanisms not directly related to stem growth and water content. It is suggested that drought might trigger signals that counteract those elicited by leaf damage. The induced twining may be an advantage in the presence of ground herbivores, but the environmental susceptibility of this response may limit its ecological significance.
\end{abstract}

KEYWORDS: Induced responses, drought, Ipomoea purpurea, resource limitation, herbivory.

\section{RESUMEN}

El ambiente puede limitar la expresión de las respuestas inducidas por la herbivoría, como el aumento en las defensas químicas o físicas. Estudios recientes en plantas trepadoras muestran que el daño foliar induce el trepado. Esta respuesta podría conferir protección contra herbívoros en terreno. En este estudio investigamos el efecto de la sequía sobre la inducción de trepado en la trepadora anual Ipomoea purpurea (Convolvulaceae), planta que en condiciones naturales puede experimentar estrés por sequía. En un experimento de invernadero, se registró la tasa de enredo (proporción de plantas que se enredan exitosamente en un tiempo dado) de plantas dañadas y no dañadas de I. purpurea, expuestas a tratamientos de riego control y sequía. También se estimó la tasa de crecimiento y el contenido hídrico del tallo, justo después de la evaluación del trepado. Las plantas en el tratamiento de sequía mostraron una reducción en la inducción de trepado por daño foliar comparado con plantas control. Ni la tasa de crecimiento ni el contenido hídrico se afectaron por el daño foliar o la sequía. Los resultados sugieren que la sequía limita la inducción de trepado por medio de mecanismos no directamente relacionados con el crecimiento y el contenido hídrico del tallo. Se sugiere que la sequía podría inducir señales que se contraponen con las generadas por el daño foliar. La inducción de trepado puede ser una ventaja en la presencia de herbívoros rastreros, pero la susceptibilidad ambiental de esta respuesta puede limitar su relevancia ecológica.

Palabras Clave: Respuestas inducidas, sequía, Ipomoea purpurea, limitación de recursos, herbivoría. 
Gayana Bot. 66(2), 2009

\section{INTRODUCTION}

Induced responses to herbivory may be constrained by environmental conditions (Gianoli \& Niemeyer 1996, Karban \& Baldwin 1997, Gianoli 2002a, Cipollini \& Bergelson 2002, Wang \& Lincoln 2004, Kurashige \& Agrawal 2005). Plants exposed to limiting conditions or to a combination of stress factors should have fewer resources to invest into inducible defenses. A particular induced response to herbivory has been described for climbing plants. Gianoli \& Molina-Montenegro (2005) reported that leaf damage increased the climbing success of the twining vine Convolvulus arvensis L. (Convolvulaceae) within 24-48 h, and that climbing modules suffered less herbivory than prostrate modules in the field. Consequently, this induced response may result in reduced damage in the future and hence may be regarded as an induced resistance mechanism. The induced twining found in $C$. arvensis seems to be a common response in the Convolvulaceae (Atala \& Gianoli 2008) and even in other plant families (Gianoli, unpublished data). The effects of environmental factors on this induced twining have not been evaluated yet. Knowledge of the influence of environmental conditions on the expression of such induced response, particularly when they involve factors that plants commonly face in the field, would be useful to assess its ecological significance.

Water is a key element for plant growth and development. One of the first consequences of water deficit in plants is a noticeable reduction of the water content of tissues (Taiz \& Zeiger 2006). Plants respond to low water availability with several morphological and physiological changes (Hsiao 1973, Grace 1997). Water stress usually affects biomass allocation, with an increased relative allocation to roots and a decrease in shoot biomass (Hunt \& Nicholls 1986). Other common phenomenon observed in water-limiting conditions is an increase in trichome density and size (Gonzáles et al. 2008), which reduces heat load over the leaf surface and hence decreases transpiration.

The tall morning glory, Ipomoea purpurea (L.) Roth (Convolvulaceae) is a twining vine that exhibits greater reproductive fitness when growing supported (Gianoli 2002b). This annual vine shows rapid induced twining after leaf damage (Atala \& Gianoli 2008). In Chile it is a common weed in regions with a Mediterranean-type climate (Matthei 1995), characterized by summer drought (Di Castri \& Hajek 1976). In natural populations I. purpurea often suffers leaf damage by chrysomelid larvae and generalist chewing insects (Atala \& Gianoli, personal observations). In the present study we evaluated the effect of water shortage on the induced twining by leaf damage of $I$. purpurea. We hypothesized that water stress would reduce shoot growth and stem water content, hence decreasing or suppressing the induced twining. This assumes that induced twining is a resource-consuming response that is not affordable under a scenario of reduced resource availability. Alternatively, it might be considered that in drought conditions, where leaf value is increased (Suárez 2005), the investment in the induced twining response could pay-off because it would avoid loosing leaf area that is hard to compensate in such conditions.

\section{MATERIALS AND METHODS}

Plants of Ipomoea purpurea were cultivated in a greenhouse located at the Universidad de Concepción, Concepción, central Chile. Seeds were collected from several parental plants grown in the same greenhouse the year before (Atala \& Gianoli 2008) and mixed in a pool. To stimulate germination, seeds were put in jars with warm water during $24 \mathrm{~h}$. Germinated seeds were put in Petri dishes with damp paper and kept in a growth chamber at $25^{\circ} \mathrm{C}$. When cotyledons were visible, seedlings were transplanted to plastic bags (1.5 1) filled with commercial potting soil and were maintained in the greenhouse. The average temperature in the greenhouse was 18.6 ${ }^{\circ} \mathrm{C}\left(37^{\circ} \mathrm{C}\right.$ maximum and $7{ }^{\circ} \mathrm{C}$ minimum). PAR radiation usually exceeded $1000 \mu \mathrm{mol} \mathrm{m}^{-2} \mathrm{~s}^{-1}$ at midday.

When plants were two weeks-old they were grouped into two water treatments: control and drought. Plants in the control and drought treatments were watered to field capacity every other day and every 10 days, respectively. We recorded $\%$ field capacity $(0-100)$ in four control and four drought plants by using gypsum blocks buried $20 \mathrm{~cm}$ into the soil and connected to a soil moisture measuring system (Eijkelkamp), which quantifies the resistance between two electrodes within the porous block. The percentage of field 
capacity in the soil in the control treatment was on average 3-times greater than that of the drought treatment during the experiment (86.17 vs. 32.04), and it was over 10-times greater at the $10^{\text {th }}$ day without watering (74.33 vs. 2.67).

When plants had five to six true leaves (approximately four weeks-old), they were allowed to twine around a plastic stake. Single-stemmed, prostrated plants were provided with a vertical stake just in contact with the stem. Plants from each water treatment described above were assigned to either damaged or undamaged treatments and were randomly placed on the greenhouse benches. Plants in the damage treatment were subjected to $50 \%$ defoliation at the beginning of the experiment. This was achieved by cutting with a scissor $50 \%$ of the leaf area of all true leaves. Leaves were clipped along the mid vein. Undamaged plants were not damaged and did not suffer attack by herbivores in the greenhouse. After inflicting leaf damage, we recorded every two hours the number of plants successfully twining around the stake $\left(360^{\circ}\right.$ gyre $)$ in each experimental group. A $360^{\circ}$ gyre corresponds to a full turn around the support. Summarizing, the four experimental groups were: undamagedcontrol water (UC, $n=19)$, damaged-control water (DC, $n=19)$, undamaged-drought (UD, $n=18)$ and damaged-drought (DD, n=17).

To evaluate the effect of water shortage on the induced twining, we calculated an induction index for each damaged plant $\left(\mathrm{I}_{\mathrm{i}}\right)$. $\mathrm{I}_{\mathrm{i}}$ was defined as the average time in hours for successful twining of plants in the undamaged treatment ( $\bar{U})$ minus the time in hours for successful twining of plant $\mathrm{i}$ in the damage treatment $\left(\mathrm{D}_{\mathrm{i}}\right)$. The index $\left(\mathrm{I}_{\mathrm{i}}=\overline{\mathrm{U}}\right.$ $\left.D_{i}\right)$ was separately calculated for damaged plants in both control watering and drought treatments. Plants from the different treatments had similar initial size (main stem length and basal stem diameter; $p>0.5$ in both cases; one-way ANOVA, data not shown). Stem growth rate (cm / day) was assessed by measuring the total length of the main stem, from the base to the tip of the apex, at the beginning of the experiment and one and seven days later. Relative growth rate after one and seven days was calculated as [(stem length at $24 \mathrm{~h}$ - initial stem length]/ initial stem length and [stem length at 7 days - initial stem length) / initial stem length] $/ 7$, respectively. This time interval spanned the time needed to observe the induced twining.
Measurements were conducted using a plastic thread. We carefully followed the path length of the main stem with the thread, which was measured afterwards. We also measured stem radial growth by recording stem diameter with a digital calliper (resolution: $0.01 \mathrm{~mm}$ ) one and seven days after the start of the experiment. After 10 days, $5 \mathrm{~cm}$ of the tip of the shoot were cut, weighted, dried for $96 \mathrm{~h}$ in an oven and then weighted again. Stem water content was estimated as relative water content $(\%=$ fresh weight $/$ dry weight $\times 100)$.

The mean induction index was compared between groups using a Mann-Whitney U test. The effects of water treatment and leaf damage on stem growth and water content were evaluated using a two-way ANOVA with Water and Damage as main factors. Variables that did not meet assumptions of parametric analysis were analysed using a Mann-Whitney $U$ test for water and damage separately.

\section{RESULTS}

The mean twining time (time to a $360^{\circ}$ turn around the support) differed significantly between damaged and undamaged plants (Table I, Mann-Whitney U-test, $\mathrm{p}<0.0004$ for DC vs UC, and $\mathrm{p}<0.044$ for DD vs UD), but not between drought-exposed and control water plants (Table I, Mann-Whitney U-test, $\mathrm{p}=0.57$ for DC vs DD and $\mathrm{p}=0.40$ for UC vs UD). The mean twining time $\pm \mathrm{SE}$ for each treatment was $\mathrm{DD}=9.50 \pm 1.61 \mathrm{~h}, \mathrm{UD}=18.78 \pm 4.73 \mathrm{~h}, \mathrm{DC}$ $=7.76 \pm 1.25 \mathrm{~h}, \mathrm{UC}=23.18 \pm 5.56 \mathrm{~h}$ (Table I). More related to our research question, drought reduced the twining induction in Ipomoea purpurea. Thus, plants under water shortage responded less to leaf damage in terms of enhanced twining compared to control plants $\left(\mathrm{I}_{\mathrm{i}}\right.$ induction index, Mann-Whitney $\mathrm{p}<0.001$, Fig. 1). Nevertheless, plants in both water treatments did show induced twining after leaf damage (see above).

Stem growth rate after one and seven days did not differ significantly between treatments (Table I; two-way ANOVA, $\mathrm{p}>0.05$ for main effects and their interaction). Likewise, both basal stem diameter and stem water content, estimated as relative water content $(\%)$, did not differ between treatments (Table I; two-way ANOVA, $\mathrm{p}>0.05$ for main effects and their interaction). 
Gayana Bot. 66(2), 2009

TABLE I. Mean \pm S.E. of stem traits and twining time of Ipomoea purpurea plants exposed to a combination of two damage and two watering treatments. The number next to the trait refers to the number of days after the beginning of the experiment in which a given trait was determined. $\mathrm{UC}=$ undamaged plants in control watering, $\mathrm{DC}=$ damaged plants in control watering, $\mathrm{UD}=$ undamaged plants in drought treatment, $\mathrm{DD}=$ damaged plants in drought treatment. $\mathrm{RGR}=$ Relative growth rate [(stem length at day X - initial stem length) / initial stem length].

TABLA I. Valor promedio \pm E.E. de rasgos del tallo y tiempo de enredo en plantas de Ipomoea purpurea expuesta a una combinación de dos tratamientos de daño y dos de riego. El número que sigue a cada atributo corresponde al número de días luego de iniciado el experimento en que se midió dicho atributo. UC = plantas no dañadas con riego control, DC $=$ plantas dañadas con riego control, $\mathrm{UD}=$ plantas no dañadas expuestas a sequía, $\mathrm{DD}=$ plantas dañadas expuestas a sequía. $\mathrm{RGR}=$ tasa relativa de crecimiento [(largo del tallo en el día X - largo inicial del tallo) / largo inicial del tallo].

\begin{tabular}{lcccc}
\hline \multicolumn{1}{c}{ Trait } & UC & DC & UD & DD \\
\hline Stem diameter 1 (mm) & $3.13 \pm 0.08$ & $3.18 \pm 0.08$ & $3.22 \pm 0.09$ & $3.16 \pm 0.09$ \\
Stem diameter 7 (mm) & $3.35 \pm 0.09$ & $3.33 \pm 0.07$ & $3.32 \pm 0.10$ & $3.27 \pm 0.08$ \\
RGR 1 (cm/day) & $0.11 \pm 0.01$ & $0.10 \pm 0.01$ & $0.11 \pm 0.01$ & $0.11 \pm 0.01$ \\
RGR 7 (cm/day) & $0.19 \pm 0.01$ & $0.18 \pm 0.01$ & $0.18 \pm 0.01$ & $0.17 \pm 0.01$ \\
Stem water content (\% water content) & $87.83 \pm 0.73$ & $87.20 \pm 0.89$ & $85.30 \pm 1.38$ & $87.33 \pm 0.61$ \\
Twining time (h) & $23.18 \pm 5.56$ & $7.76 \pm 1.25$ & $18.78 \pm 4.73$ & $9.50 \pm 1.61$
\end{tabular}

\section{DISCUSSION}

Experimental drought limited the induced twining by leaf damage in Ipomoea purpurea (Fig. 1). There is evidence that water shortage may constrain some induced responses to herbivory in plants (Lewinsohn et al. 1993, Lombardero et al. 2000). Since all plants eventually twine and stem growth rate was similar across treatments, the phenomenon of induced twining seems to be relevant for the initial finding of and successful twining onto a suitable support, but it is not related to enhanced growth or ascension rate. A similar result was found in the induced twining of $C$. arvensis (Gianoli \& Molina-Montenegro 2005), thereby suggesting that a change in climbing behaviour is underlying the observed advantage in finding a support for damaged plants. The reduction in the induced twining in drought conditions implies that waterstressed prostrate plants could be more susceptible to ground herbivores and hence less likely to survive the stress episode. This result somewhat questions the ecological significance of the induced twining of Ipomoea purpurea plants naturally growing in central Chile, where drought is common during the summer (Di Castri \& Hajek 1976).

The induced twining in Ipomoea purpurea is also elicited by jasmonic acid (Atala \& Gianoli
2008), a molecule related to several plant responses to leaf damage (Reinbothe et al. 1994, Albrecht et al. 1993, Karban \& Baldwin 1997). It might be speculated that drought and leaf damage trigger opposing signals, probably linked to the jasmonate pathway, resulting in a reduced expression of induced twining. Nevertheless, jasmonate activity has been reported to be involved in several plant responses to drought (Gao et al. 2004). Moreover, in some cases drought (or drought-related signals) can elicit jasmonate-related compounds similar to those elicited by leaf damage (Do et al. 2004). It is unclear how drought and damage signals are integrated by the plant in connection with the induced twining. Further studies are required to understand the molecular pathway leading from leaf damage to increased twining and how other environmental stimuli may alter such pathway. Interestingly, some non-defensive responses to herbivory oppose plant responses to drought. For example, relative biomass allocation to shoots and photosynthesis increase with herbivory and decrease with water shortage (Nowak \& Caldwell 2004, Schulze 1986, Mabry \& Wayne 1997, Gianoli \& González-Teuber 2005).

Surprisingly, despite the marked differences in soil moisture, there were no differences in stem water content between water treatments. This might 


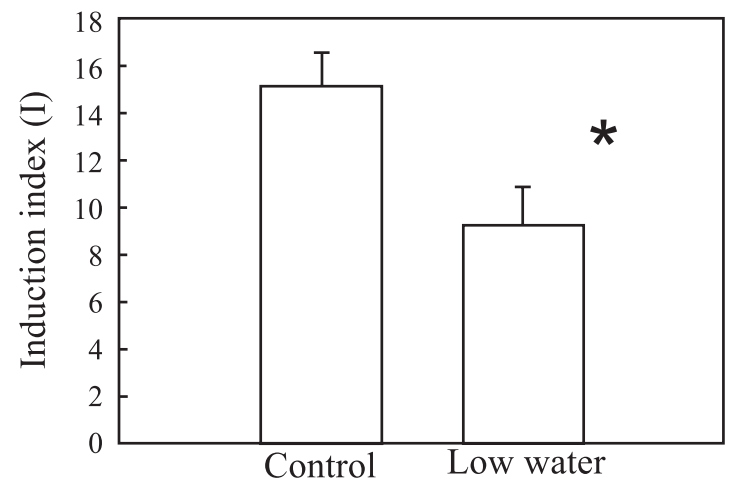

FIGURE 1. Induction index $\left(\mathrm{I}_{\mathrm{i}}\right)$ in control water and drought plants of Ipomoea purpurea. Induction index was calculated as the difference between the average twining time (h) for undamaged plants ( $\overline{\mathrm{U}})$ and each individual twining time in the damage treatment $\left(D_{i}\right)$. Thus, $I_{i}=\bar{U}-D_{i}$. Thus, we obtained an induction index value for each plant in the damage treatment. Asterisk indicates significant differences between groups $(\mathrm{p}<0.001$; Mann-Whitney test).

Figura 1. Índice de inducción (I.) en plantas de Ipomoea purpurea con riego control y sequía. El índice de inducción se calculó como la diferencia entre el tiempo de enredo promedio (h) de las plantas no dañadas (Ū) y cada tiempo de enredo individual en el tratamiento de daño $\left(\mathrm{D}_{\mathrm{i}}\right)$. Así, $\mathrm{I}_{\mathrm{i}}=\overline{\mathrm{U}}-\mathrm{D}_{\mathrm{i}}$. De esta forma, obtuvimos un valor de índice de inducción para cada planta en el tratamiento de daño. El asterisco indica diferencias significativas entre grupos $(\mathrm{p}<0.001$; test de Mann-Whitney).

be a consequence of differential water allocation within the plant. We measured water content in the tip of the stem involved in the twining process. It is possible that in plants under experimental drought, water was preferentially assigned to the growing tip or runner. The runner of climbing plants often shows distinctive physiological features, such as the cessation of leaf development, that are thought to enhance the possibility of searching for support (French 1977, Ruiz-Fernández 1987). In another Ipomoea species, exploration by almost-leafless creeping shoots is thought to represent growth subsidized by other plant parts (Peñalosa 1983). Alternatively, it might be conceived that the drought treatment was insufficient to affect the plant water status. I. purpurea is naturally exposed to summer drought in central Chile during the growth season and might be somewhat adapted to water shortage.

It has been discussed that the induced twining after leaf damage may confer protection against further herbivory in climbing plants (Gianoli \& Molina-Montenegro 2005, Atala \& Gianoli 2008, González-Teuber \& Gianoli 2008). However, this response is to some extent constrained by water availability, probably due to the simultaneous response of several traits to environmental stress. Further research should address the molecular basis of such reduced induction under water shortage. The ecological significance of this particular attribute of twining vines might be questioned, at least in habitats where water deficit occurs. Evidence from field experiments is needed and will shed light into this issue.

\section{ACKNOWLEDGMENTS}

This work was funded by CONICYT (Comisión Nacional de Ciencia y Tecnología) thesis grant AT-24050056. CA was supported by a CONICYT doctoral fellowship during the development of this study.

\section{REFERENCES}

Albrecht, T., A. Kehlen, K. Stahl, H.-D. Knofel, G. Sembder \& E.W. Weiler. 1993. Quantification of rapid, transient increases in jasmonic acid in wounded plants using a monoclonal antibody. Planta 191: 86-94.

Atala, C. \& E. Gianoli. 2008. Induced twining in Convolvulaceae climbing plants in response to leaf damage. Botany 86: 595-602.

Cipollini, D.F. \& J. Bergelson. 2002. Interspecific 
Gayana Bot. 66(2), 2009

competition affects growth and herbivore damage of Brassica napus in the field. Plant Ecology 162: 227-231.

Di Castri, F. \& E.R. Hajek. 1976. Bioclimatología de Chile. Editorial de la Universidad Católica de Chile, Santiago, Chile. 129 pp.

Do, H.M., S.C. Lee, H.W. Jung, K.H. Sohn \& B.K. Hwang. 2004. Differential expression and in situ localization of a pepper defensin (CADEF1) gene in response to pathogen infection, abiotic elicitors and environmental stresses in Capsicum annuum. Plant Science 166: 1297-1305.

FrenCH, J.C. 1977. Growth relationship of leaves and internodes in viny angiosperms with different modes of attachment. American Journal of Botany 64: 292-304.

GaO, X.P., X.F. WANG, Y.F. Lu, L.Y. Zhang, Y.Y. Shen, Z. LiAng \& D.P. Zhang. 2004. Jasmonic acid is involved in the water-stress-induced betaine accumulation in pear leaves. Plant Cell and Environment 27: 497-507.

Gianoli, E. 2002a. A phenotypic trade-off between constitutive defenses and induced responses in wheat seedlings. Ecoscience 9: 482-488.

Gianoli, E. 2002b. Maternal environmental effects on the phenotypic responses of the twining vine Ipomoea purpurea to support availability. Oikos 99: 324-330.

Gianoli, E. \& M. GonZÁLEZ-Teuber. 2005. Environmental heterogeneity and population differentiation in plasticity to drought in Convolvulus chilensis (Convolvulaceae). Evolutionary Ecology 19: 603-613.

Gianoli, E. \& M.A. Molina-Montenegro. 2005. Leaf damage induces twining in a climbing plant. New Phytologist 167: 385-390.

GiANOLI, E. \& H.M. NiEMEYER. 1996. Environmental effects on the induction of wheat chemical defences by aphid infestation. Oecologia 107: 549-552.

GonzÁles, W.L., M.A. Negritto, L.H. SuÁrez \& E. GiANOLI. 2008. Differential induction of glandular and non-glandular trichomes by damage in leaves of Madia sativa under contrasting water regimes. Acta Oecologica 33: 128-132.

GonzÁlez-Teuber, M. \& E. Gianoli. 2008. Damage and shade enhance climbing and promote associational resistance in a climbing plant. Journal of Ecology 96: 122-126.

Grace, J. 1997. Plant water relations. In: M.J. Crawley (ed.), Plant Ecology, pp. 28-50. Blackwell, Oxford, UK.

Hsiao, T.C. 1973. Plant responses to water stress. Annual Review of Plant Physiology 24: 519-570.

Hunt, R. \& A.O. Nicholls. 1986. Stress and the coarse control of growth and root-shoot partitioning in herbaceous plants. Oikos 47: 149-158.

Karban, R. \& I.T. BaLdwin. 1997. Induced Responses to Herbivory. University of Chicago Press, Chicago, IL, USA. 319 pp.

Kurashige, N.S. \& A.A. Agrawal. 2005. Phenotypic plasticity to light competition and herbivory in Chenopodium album (Chenopodiaceae). American Journal of Botany 92: 21-26.

Lewinsohn, E., M. GiJzen, R.M. Muzika, K. Barton \& R. Croteau. 1993. Oleoresinosis in grand fir (Abies grandis) saplings and mature trees - modulation of this wound response by light and water stresses. Plant Physiology 101: 1021-1028.

Lombardero, M.J., M.P. Ayres, P.L. Lorio \& J.J. Ruel. 2000. Environmental effects on constitutive and inducible resin defences of Pinus taeda. Ecology Letters 3: 329-339.

Mabry, C.M. \& P.W. Wayne. 1997. Defoliation of the annual herb Abutilon theophrasti: mechanisms underlying reproductive compensation. Oecologia 111: 225-232

Matthei, O. 1995. Manual de las malezas que crecen en Chile. Alfabeta Impresores, Santiago, Chile. $545 \mathrm{pp}$.

NowaK, R.S. \& M.M. Caldwell. 2004. A test of compensatory photosynthesis in the field: Implications for herbivory tolerance. Oecologia 61: 311-318

Peñalosa, J. 1983. Shoot dynamics and adaptive morphology of Ipomoea phillomega (Veil.) House (Convolvulaceae), a tropical rainforest liana. Annals of Botany 52: 737-754.

Reinbothe, S., B. Mollenhauer \& C. Reinbothe. 1994. JIPs and RIPs, The regulation of plant gene expression by jasmonates in response to environmental cues and pathogens. Plant Cell 6: 1197-1209.

Ruiz-FernÁNDEZ, S. 1987. Auswirkungen der Kletterstrategie der Lianen aufderen Verbreitung. Tuexenia 7: 447-458.

Schulze, E.D. 1986. Whole-plant responses to drought. Australian Journal of Plant Physiology 13: 127-141.

SuÁrez, N. 2005. Leaf construction cost in Avicennia germinans as affected by salinity under field conditions. Biologia Plantarum 49: 111-116,

Taiz, L. \& E. Zeiger. 2006. Plant Physiology, 4th edn. Sinauer Associates, Inc. Massachusetts, USA. $764 \mathrm{pp}$.

WANG, M. \& D.E. Lincoln. 2004. Effects of light intensity and artificial wounding on monoterpene production in Myrica cerifera from two different ecological habitats. Canadian Journal of Botany 82: 1501-1508.

Recibido: 14.01.09

Aceptado: 04.05.09 